DOI: https://doi.org/10.32689/2618-0065-2020-2(4)-168-178

Кальниш Юрій Григорович, доктор наук з державного управління, професор, професор кафедри соціології, Дніпровський національний університет імені. Олеся Гончара, 49000, м. Дніпро, проспект Гагаріна, 72, тел.: +38 05099387 77, e-mail: ukalnish@gmail.com, https//orcid.org/0000-0001-91851094

\title{
КОНЦЕПТУАЛЬНІ ЗАСАДИ ФОРМУВАННЯ КУЛЬТУРИ УЧАСТІ ГРОМАДЯН В ПРОЦЕСІ МОДЕРНІЗАЦІЇ СИСТЕМИ ПУБЛІЧНОГО УПРАВЛІННЯ
}

Анотація. Мета дослідження, результати якого висвітлені в цій статті, полягає в тому, щоб визначити, укласти в логічно-цілісну систему та описати концептуальні засади формування учасницької культури громадянського суспільства, 3 метою подальшого визначення на їх основі відповідних публічно-управлінських механізмів.

Автор констатує, що процес публічного управління втілюється в системному комплексі складових, що загалом формують культуру його учасників. Фундаментальними складовими культури учасників публічноуправлінського процесу $є$ : політико-правова грамотність; демократична свідомість; громадянська поведінка.

Автор зазначає, що у сучасному світі нема розвиненого цивілізованого суспільства, в якому не використовувалося б, не культивувалося б поняття "учасницька демократія". Тому правильне розуміння тих явищ, які цим поняттям відображаються, набуває безпосередньо світоглядного значення. Світогляд людини не може бути повним, досконалим якщо у ньому відсутні знання щодо сутності демократії. Отже формування культури демократичної участі $\epsilon$ важливим складником формування особистості громадянина i громадянської культури суспільства загалом. Саме тому цим питанням зараз в Україні надається найважливішого значення.

Загальну структуру культури громадських учасників публічноуправлінського процесу і послідовність їі формування автори представляють у вигляді цілісної функціональної системи, окремі складові якої тісно пов’язані, розвиваються у взаємодії поступово, послідовно або одночасно. Відповідно до складових описаної структури учасницької культури, держава, як об'єктивно зацікавлений учасник демократичного процесу публічного управління повинна застосовувати певні управлінські механізми впливу на формування цієї культури. В узагальненому вигляді до числа таких державно-управлінських 
механізмів слід віднести: стримування, заохочування, сприяння, спостереження та реагування.

Ключові слова: публічне управління, демократія, участь, громадянське суспільство.

Kalnysh, Yuri Grigorovich Doctor of Sciences in Public Administration, Professor, Professor of the Department of Sociology, Dniprovsky National University. Olesya Gonchar, 49000, Dnipro, Gagarin Avenue, 72, tel .: +38 050993 87 77, e-mail: ukalnish@gmail.com, https//orcid.org/0000-0001-9185-1094

\title{
CONCEPTUAL FOUNDATIONS FOR THE CULTURE OF CIVIL PARTICIPATION IN THE PROCESS OF MODERNIZATION OF THE PUBLIC GOVERNANCE SYSTEM
}

\begin{abstract}
The purpose of the study, the results of which are highlighted in this article, is to identify, integrate into a logistically integrated system and describe the conceptual foundations for building a participatory culture of the civil society, with a view to further identifying appropriate public-administrative mechanisms on their basis.

The author states that the process of public administration is embodied in a systemic set of components that generally shape the culture of its participants. The fundamental components of the culture of participants in the public-administrative process are: political-legal literacy; democratic consciousness; civic behaviour.

The author notes that in the modern world there is no developed civilized society in which the concept of "participatory democracy" would not be used or cultivated. Therefore, a proper understanding of the phenomena that are reflected in this concept becomes directly ideological. A person's worldview cannot be complete, perfect if he or she lacks knowledge of the essence of democracy. Thus, the formation of a culture of democratic participation is an important component of the formation of the personality of the citizen and of the civic culture of the society in general. That is why these issues are now of paramount importance in Ukraine.

The authors present the general structure of the culture of the public participants in the public-administrative process and the sequence of its formation in the form of a coherent functional system, the individual components of which are closely related, developing in a gradual, sequential or simultaneous manner. According to the components of the described structure of the participatory culture, the state, as an objectively interested participant in the democratic process of the public administration, should apply certain administrative mechanisms to influence the formation of that culture. In summary, the following public-administrative mechanisms include: restraint, encouragement, promotion, observation and response.

Keywords: public administration, democracy, participation, civil society.
\end{abstract}


Постановка проблеми. Широке та всебічне залучення громадян до свідомої активної співпраці в процесі національного державотворення, забезпечення їх конституційного права на участь в управлінні державними справами та місцевому самоврядуванні $\epsilon$, без перебільшення, найпотужнішим, механізмом втілення демократії в сучасному громадянському суспільстві. В країнах розвиненої демократії, як на рівні національного законодавства, так і на рівні урядової політики та в діяльності місцевих органів влади й органів місцевого самоврядування функціонує історично і культурно сформована на протязі століть система здійснення загального народовладдя. Отже ми цілком маємо право казати про існування певної культури учасницького процесу в громадянському суспільстві. До того ж, в правовій державі ця культура насамперед - правова. Звичайно, що носіями цієї культури є не лише органи державної влади, а й безпосередньо громадяни країни.

На жаль, в нашій країні досі мають місце деякі складності у формуванні учасницької (лат. participatio) культури громадянського суспільства. Ці складності відчувалися протягом всього процесу незалежного державотворення. Час від часу проблема несформованості культури політичної участі населення України загострюється, призводячи до екстремальних ситуацій в державі. Найактуальнішими серед проблем учасницької культури суспільства в Україні лишаються:

- наявність у свідомості громадян України, які належать до старшого покоління i являють в сукупності значну частку політично активного населення, певного антагонізму культури участі, що світоглядно детермінований політичною культурою тоталітарної держави, частиною якої була Україна;

- не висока правова і політична грамотність основної частини населення, певна апатія, настороженість, інколи - роздратованість у стосунках 3 державою. Актуальним лишається питання підвищення довіри населення до влади;

- низька політична активність і взагалі громадянська пасивність значної частини української молоді, політично розчарованої і незадоволеної своїм соціальним становищем.

На хвилі революційних подій соціологи спостерігали певні зміни суспільно-політичної свідомості, які свідчили на користь підйому учасницької культури значної частини населення України. Однак, цими висновками не слід захоплюватися. Практику революційних збурень абсолютно не варто зараховувати в актив учасницької культури демократичного суспільства. Навіть культура політичного протесту має бути відпрацьованою громадянським суспільством найкращим чином.

На цьому фоні найбільш активні учасники політичного процесу суб'єкти влади, політична еліта - відповідно формують власну свідомість і 
політичну культуру, зокрема у виборчому процесі в якій, на жаль, завжди лишається місце різного роду зловживанням.

Ці проблеми гостро відчуваються. Але, 3 рештою, в українському суспільстві переважають позитивні процеси демократичного державотворення, про що свідчить досвід останніх президентських виборів і реформаторські прагнення нової влади.

Аналіз останніх досліджень і публікацій. Питання про шляхи формування учасницької культури демократичного громадянського суспільства в Україні не є новим для зарубіжної [1 - 7 та ін.] та вітчизняної суспільствознавчої науки [8 - 12 та ін. ]. Однак, за відсутності чітких публічноуправлінських механізмів, процес формування учасницької культури населення i досі розвивається хаотично, загрожуючи суспільству деструктивними рецидивами недемократичних політичних ідеологій.

Мета дослідження, результати якого висвітлені в цій статті, полягає в тому, щоб визначити, укласти в логічно-цілісну систему та описати концептуальні засади формування учасницької культури громадянського суспільства, 3 метою подальшого визначення на їх основі відповідних публічно-управлінських механізмів.

Виклад основного матеріалу. Процес публічного управління втілюється в системному комплексі складових, що загалом формують культуру його учасників. Фундаментальними складовими культури учасників публічноуправлінського процесу $є$ : політико-правова грамотність; демократична свідомість; громадянська поведінка.

Політико-правова грамотність являе собою сукупність знань громадянами своїх конституційних прав і обов’язків, розуміння механізмів дії і взаємодії складових політичного та публічно-управлінського процесів й усвідомлення свого місця і ролі у цих процесах. Отже, ключовим поняттями політико-правової грамотності громадян є: знання, розуміння і усвідомлення. Цим визначаються i основні засоби підвищення політико-правової грамотності, а саме:

- активне поширення політичної та правової інформації, широке розповсюдження матеріалів 3 питань політичного процесу, процесів публічного управління та різного роду правової інформації в демократичному суспільстві. Як і Конституція України, ці інформаційні матеріали повинні бути легко доступними для громадянина. В ідеалі - не лише в офіційних виданнях держави чи бібліотеках, а насамперед у загальнодоступних засобах масової інформації, навіть у власній поштовій скриньці кожен громадянин має знайти невеликі за обсягом популярні видання 3 політичних, правових, адміністративних питань;

- активне роз’яснення особливостей політичного, правотворчого, публічно-управлінського процесів, створення різного роду наукових і науковопрактичних коментарів до них, запровадження низки просвітніх заходів. На 
робочому місці, за місцем проживання чи навчання кожен громадянин має отримати змогу відвідати безкоштовно лекторії з політико-правової освіти;

- активна пропаганда учасницького процесу - включає в себе, насамперед, організацію низки громадських заходів на підтримку демократичного державотворення, створення інформаційних i навчальних радіо- ,теле- та Інтернет- програм, іншу агітацію з метою залучення до участі у публічно-управлінському процесі якомога більшого кола громадян. При організації цих заходів державою, місцевими органами виконавчої влади, неодмінної умовою є утримання від агітації за будь-яку конкретну політичну програму, партію, виборчий блок чи політика. Адже метою пропаганди учасницького процесу є сприяння усвідомленню громадянами свого місця i ролі у ньому, спонукання їх до активної участі у справах держави, а ні в якому разі не підтримка державою певної політичної ідеології, що само по собі вже буде порушенням Конституції України.

Таким чином, ключовим поняттям формування політико-правової грамотності громадян відповідають засоби:

- поширення політико-правової інформації - знання;

- роз’яснення політико-правової інформації - розуміння;

- пропаганда демократії - усвідомлення.

Демократична концепція громадянської освіти населення передбачає доступність, відкритість і прозорість інформації; політичний плюралізм і доктринальну неупередженість; об’єктивність висвітлення політичного процесу.

Демократична свідомість громадянина являє собою світоглядну основу поведінки суб’єкта публічно-управлінського процесу, яка грунтується на політико-правовій грамотності i визначає систему поглядів й моральноетичних норм щодо його участі у цьому процесі.

В демократичному громадянському суспільстві демократична свідомість громадянина складається 3 ключових понять: лояльність, переконаність, активність.

Лояльність (від франи. loyal - чесний, вірний) громадянина - це, насамперед, повага до Конституції та законодавства країни, коректність, відмова від будь-яких протиправних чи осудних або недоброзичливих дій, висловлювань стосовно держави тощо.

Демократична переконаність громадянина полягає в усвідомленні ним справедливості державної влади, іiї ефективності, суспільній корисності. Але, насамперед, це впевненість громадянина в тому, що його громадянські права ні в якому разі не будуть утиснуті.

Ми знаємо приклади в законодавстві навіть тих країн, суспільнополітичний устрій яких розглядається як один із класичних зразків демократії, коли громадяни заохочуються до участі у політичному процесі через пряму дію норм виборчого законодавства. Участь у виборах розглядається як неодмінний 
громадський обов’язок, а неучасть - карається різного роду формальними стягненнями. На відміну від таких засобів, реальна політична активність громадян, яка грунтується на їх переконаності $\epsilon$, без сумніву, більшою запорукою ефективності публічно-управлінського процесу.

3 цією метою здійснюється вивчення апробованих і пошуку нових форм пропаганди й організації роботи з населенням і засобами масової інформації, ознайомлення 3 методами аналізу та прогнозування участі громадян у публічно-управлінському процесі, усвідомлення обов'язковості додержання Конституції та законодавства. Тут важлива роль належить лекторіям, політико-правовим клубам і центрам, що можуть утворюватися політичними партіями та іншими об’єднаннями громадян. Демократична держава має сприяти подібній діяльності цих громадянських інституцій.

Не останню роль в процесі вироблення та реалізації публічної політики, спрямованої на формування політичної лояльності громадян відіграє політичний моніторинг суспільної свідомості населення. В демократичному суспільстві влада, як ніхто інший, зацікавлена в тому, щоб знати політичні настрої своїх громадян, принаймні з метою вжиття заходів для формування власного позитивного політичного іміджу.

3 рештою, вищою формою втілення політичної культури громадян $є$ їх громадянська поведінка. У найширшому вигляді громадянська поведінка свідомих учасників публічно-управлінського процесу не зводиться лише до реалізації конституційних прав i обов'язків (здійснення їх приписів у практичних діях) і включає в себе крім: дотримання, виконання, використання ще і пропагування складових цивілізованого демократичного процесу.

- дотримання норм демократичного процесу - форма реалізації забороняючих правових норм, яка полягає у пасивний поведінці суб'єктів, вчинюваній незалежно від їх власного бажання (наприклад, неприпустимість: пропаганди фашизму, війни; розпалювання національної та релігійної ворожнечі; змови з метою повалення конституційного ладу; тероризму тощо);

- виконання норм демократичного процесу - форма реалізації зобов’язуючих правових норм, яка полягає в активній поведінці суб'єктів що здійснюється ними незалежно від їх власного бажання (наприклад, захист своєї країни, сплата податків, запобігання протиправним діям інших осіб тощо);

- використання норм демократичного процесу - форма реалізації уповноважуючих правових норм, яка полягає в активній поведінці суб'єктів, що здійснюється ними за їх власним бажанням (наприклад, об'єднання в політичні партії. участь у виборах, проведення громадянських акцій тощо);

- пропагування демократичного процесу - не є обов’язковою формою громадянської поведінки, але вона є бажаною складовою для громадянськосвідомого учасника публічно-управлінського процесу, будь то сам громадянин, політична партія, чи громадська організація або державний орган, який забезпечує демократичний процес. 
Крім власної свідомості громадян - учасників демократичного процесу, головним гарантом їх правової поведінки в цьому процесі є держава. Отже, органи виконавчої влади повинні:

- оперативно вживати необхідних заходів для забезпечення неухильного дотримання посадовими особами вимог Конституції та законодавства 3 питань забезпечення публічного управління, що належать до їх відання;

- сприяти, разом з державними та комунальними засобами масової інформації, правоохоронними органами, діяльності утворюваних політичними партіями та громадськими організаціями просвітницьких центрів 3 метою всебічного висвітлення публічно-управлінського процесу та оперативного поширення політико-правової інформації тощо.

Таким чином можна представити загальну структуру культури громадських учасників публічно-управлінського процесу і послідовність іiі формування (Рис. 1) у вигляді цілісної функціональної системи, окремі складові якої тісно пов’язані, розвиваються у взаємодії поступово, послідовно або одночасно.

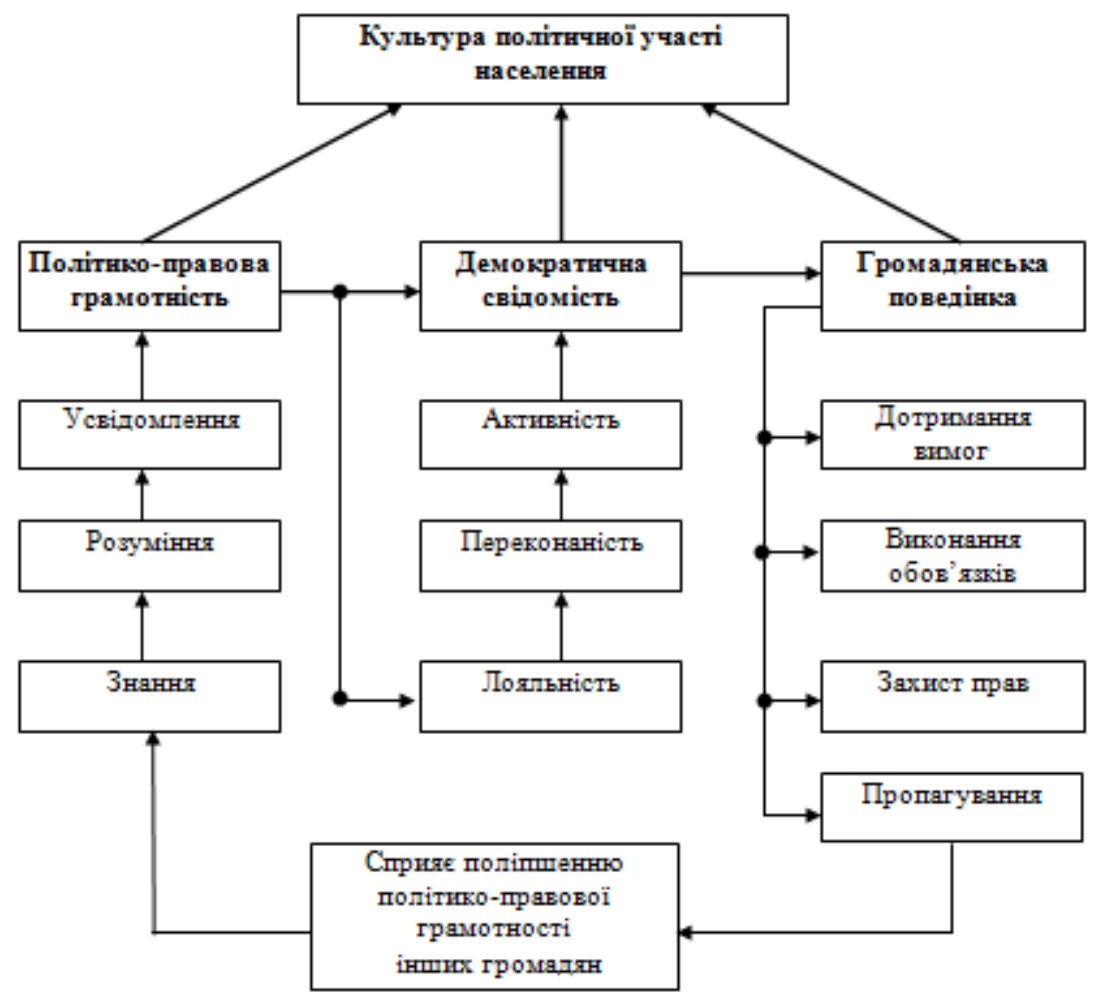

Рис 1. Загальна структура культури учасників публічно-управлінського процесу та логіка іï формування

Відповідно до складових описаної структури учасницької культури, держава, як об'єктивно зацікавлений учасник демократичного процесу публічного управління повинна застосовувати певні управлінські механізми впливу на формування цієї культури. В узагальненому вигляді до числа таких 
державно-управлінських механізмів слід віднести: стримування, заохочування, сприяння, спостереження та реагування.

При формування структури політико-правової грамотності громадян доцільно застосовувати механізми заохочування та сприяння. Держава доступними їй засобами заохочує право-просвітницьку та політикоінформаційну діяльність політичних партій, громадських організацій, навчальних закладів, засобів масової інформації, науковців. Держава також, через органи виконавчої влади та органи місцевого самоврядування сприяє цій діяльності шляхом цільового фінансування, надання пільгового оподаткування, безкоштовного ефірного часу тощо.

При формування структури демократичної свідомості громадян ефективними зарекомендували себе засоби спостереження та реагування. Відповідним органам державної влади та органами місцевого самоврядування, силами професійних наукових спільнот, потрібно організувати активний процес політичного моніторингу громадської думки. На основі результатів цього моніторингу слід своєчасно вносити корективи в публічну політику на національному, регіональному та місцевому рівнях, при потребі - вживати додаткових роз'яснювальних заходів.

При формування структури громадянської поведінки населення як правило вживаються заходи заохочування та сприяння, але при потребі - й стримування. В усіх випадках тут дуже важливо не допускати відання переваги лише певним політично орієнтованим структурам громадянського суспільства. У останньому випадку головне, щоб заходи стримування здійснювалися виключно в правовому полі.

На останок, слід зазначити, що у сучасному світі нема розвиненого цивілізованого суспільства, в якому не використовувалося б, не культивувалося б поняття "учасницька демократія". Тому правильне розуміння тих явищ, які цим поняттям відображаються, набуває безпосередньо світоглядного значення. Світогляд людини не може бути повним, досконалим якщо у ньому відсутні знання щодо сутності демократії. Отже формування культури демократичної участі $\epsilon$ важливим складником формування особистості громадянина і громадянської культури суспільства загалом. Саме тому цим питанням зараз в Україні надається найважливішого значення.

Висновки. 3 метою забезпечення широкої та всебічної, свідомої участі громадян в публічно-управлінському процесі, зміцнення в Україні народовладдя, розвитку громадянського суспільства надалі потрібно:

1. Визнати створення ефективних організаційних і правових умов для всебічного підвищення культури політичної участі громадян, формування високої громадянської свідомості, патріотизму та політичної активності населення України, зміцнення гарантій реалізації громадянами конституційного права на участь в управлінні державними справами, підтримання постійного політичного діалогу з усіма соціальними групами 
громадян, створення можливостей для вільного, об’єктивного висвітлення публічно-управлінських процесів засобами масової інформації, пріоритетними завданнями Кабінету Міністрів України, центральних та місцевих органів виконавчої влади.

2. Кабінету Міністрів України:

- сприяти політико-просвітницькій діяльності політичних партій тагромадсько-політичних об’єднань;

- здійснити додаткові заходи із запровадження більш ефективних форм роботи органів виконавчої влади, спрямованої на підвищення культури політичної участі громадян, формування їх високої демократичної свідомості, патріотизмута політичної активності населення України;

- розробити і затвердити Положення про політико-правову просвітницьку роботу органів виконавчої влади з населенням;

- забезпечити створення консультаційних центрів політико-правової просвітницької роботи з населенням при Кабінеті Міністрів України, місцевих державних адміністрація, для здійснення організації та координації заходів із підвищення культури політичної участі громадян, залучивши до роботи в них представників політичних партій, громадських об’єднань, органів місцевого самоврядування та засобів масової інформації, затвердити відповідні положення про такі центри, створити необхідні умови для їх роботи;

- організувати із залученням засобів масової інформації широке роз'яснення політичних процесів, ролі та можливостей участі громадян в реалізації публічно-управлінської діяльності, значення їх активної конструктивної участів політичному житті для сучасного національного державотворення, ефективного вироблення та реалізації публічної політики.

3. Міністерствам, іншим центральним органами виконавчої влади, місцевим державним адміністраціям:

- ужити заходів, спрямованих на розвиток партнерських відносин 3 політичним партіями, громадсько-політичними об’єднаннями, політично активними групами населення України, з метою забезпечення всебічного підвищенняефективності їх політико-правової просвітницької діяльності;

- вживати додаткових роз'яснювальних заходів 3 метою попередження деструктивних проявів політичної активності населення;

4. Міністерству освіти і науки України разом із міністерствами, іншими центральним органами виконавчої влади, у сфері управління яких перебувають навчальні заклади, забезпечити у процесі підготовки, перепідготовки та підвищення кваліфікації фахівців за напрямом "Публічне управління та адміністрування" більш широке вивчення сучасних політичних технологій, політичної аналітики та методів організації й проведення політико-правової просвітницької роботи з населенням. А також, розробити та впровадити цикли політико-правових просвітницьких лекцій i започаткувати серію науково- 
просвітницьких популярних видань 3 тематики політичної участі для населення.

5. Пріоритетною перспективою подальших наукових досліджень $є$ розроблення інноваційних технологій впровадження, модернізації та оптимізації механізмів учасницької (партисипативної) демократії в системі публічного управління сучасної України.

\section{Лimepamypa:}

1. Jenkins, Henry, etc. (2006) Confronting the Challenges of Participatory Culture: Media Education for the 21st Century. MacArthur Foundation, $136 \mathrm{p.}$

2. Jenkins, Henry, Ito, Mizuko (2015) Participatory Culture in a Networked Era: A Conversation on Youth, Learning, Commerce, and Politics. Polity. 160 p.

3. Massanari, Adrienne (2015) Participatory Culture, Community, and Play: Learning from Reddit. Political Science. https://www.semanticscholar.org/paper/ Participatory-Culture\%2CCommunity\%2C-and-Play\%3A-from-Massanari/b097602 534ddab766207abd1f4b2bfff477d94ff.

4. Ross, Andrew S., Rivers Damian J. (2018) Discourses of Legitimization Participatory Culture in Digital Contexts. 1st Edition. New York. Routledge. 378 p.

5. Jenkins, Henry (2019) Participatory Culture: Interviews. Polity. 240 p.

6. Carrie Lynn D. Reinhard, Christopher J. Olson (2019) Convergent Wrestling: Participatory Culture, Transmedia Storytelling, and Intertextuality in the Squared Circle. 1st Edition. The Political Politics of Media and Popular Culture. Routledge. 204 p.

7. Lüneburg, Barbara (2019) TransCoding: From "Highbrow Art" to Participatory Culture: Social Media - Art - Research. Culture \& Theory. 204 p.

8. Савельєв Ю. Б. (2017) Багатовимірна сучасність: соціальне включення в оцінці суспільного розвитку. Київ : ВПЦ "Київський університет", 447 с.

9. Розвиток територіальних громад в умовах децентралізації: правові, економічні та соціальні аспекти: Матеріали наук.-практ. конф. (2018), Миколаїв : МНАУ, 424 с.

10. Karpenko O., etc. (2018) The concept of cultural competence of the digital governance specialists within public administration. Bulletin of the National Academy of Art and Culture Leadership: Scientific Journal. 3. c. 14-18.

11. Карпенко О. та ін. (2019) Партисипативні трансформації на місцевому рівні: електронна та цифрова демократія. Актуальні проблеми державного управління: Збірник наукових праць ОРІДУ. 1(77). с. 111-115.

12. Zhuravel, Yaroslav, Kravchenko, Viktor. (2019) The development of participatory democracy is an important factor in improving governance in the united territorial communities. Public Administration Aspects: Scientific journal. 7 (3). p. 59 - 65.

\section{References:}

1. Jenkins, H., et al. (2006). Confronting the Challenges of Participatory Culture: Media Education for the 21st Century. MacArthur Foundation [in English].

2. Jenkins, H., Ito, M., Boyd, D. (2015). Participatory Culture in a Networked Era: A Conversation on Youth, Learning, Commerce, and Politics. Polity [in English].

3. Massanari, A. (2015). Participatory Culture, Community, and Play: Learning from Reddit. Political Science. Retrieved from https://www.semanticscholar.org/paper/ParticipatoryCulture\%2C-Community\%2C-and-Play\%3A-from-

Massanari/b097602534ddab766207abd1f4b2bfff477d94ff [in English].

4. Ross, A.S., Rivers, D.J. (2018). Discourses of Legitimization Participatory Culture in Digital Contexts. (1st ed.). New York: Routledge [in English]. 
5. Jenkins, H. (2019). Participatory Culture: Interviews. Polity [in English].

6. Reinhard, C.L.D., Olson, C.J. (2019). Convergent Wrestling: Participatory Culture, Transmedia Storytelling, and Intertextuality in the Squared Circle. (1st ed.). Routledge [in English].

7. Lüneburg, B. (2019). TransCoding: From "Highbrow Art" to Participatory Culture: Social Media - Art - Research (Culture \& Theory). Transcript-Verlag [in English].

8. Savelyev, Yu. B. (2017). Bahatovymirna suchasnist: sotsialne vklyuchennya $v$ otsintsi suspilnoho rozvytku [Multidimensional modernity: social inclusion in the assessment of social development]. Kyiv : VPTS "Kyyivskyy universytet" [in Ukrainian].

9. Rozvytok terytorialnykh hromad v umovakh detsentralizatsiyi: pravovi, ekonomichni ta sotsialni aspekty [Development of territorial communities under decentralization: legal, economic and social aspects]. Proceedings of scientific-practical Conference. (2018). Mykolayiv: MNAU [in Ukrainian].

10. Karpenko, O., et al. (2018). The concept of cultural competence of the digital governance specialists within public administration. Bulletin of the National Academy of Art and Culture Leadership: Scientific Journal, 3, 14-18 [in English].

11. Karpenko, O., et al. (2019). Partysypatyvni transformatsiyi na mistsevomu rivni: elektronna ta tsyfrova demokratiya [Local Party-Driven Transformations: Electronic and Digital Democracy]. Aktualni problemy derzhavnoho upravlinnya - Actual problems of public administration, 1(77), 111-115 [in Ukrainian].

12. Zhuravel, Ya., Kravchenko, V. (2019). The development of participatory democracy is an important factor in improving governance in the united territorial communities. Public Administration Aspects, 7(3), 59-65 [in English]. 